\title{
THE USE OF PHOTOGRAMMETRY FOR SPECIAL FLIGHT TESTS
} \section{WYKORZYSTANIE FOTOGRAMETRII DO PRÓB SPECJALNYCH W LOCIE*}

\begin{abstract}
Carrying out flight tests of de-icing systems of aircraft in real or artificial conditions, apart from the measurement of the temperature of the heated areas, requires the verification of the work of the installations in the form assessment of the places of the formation of ice accretions rate and their size. To measure them in the mentioned about tests the authors applied the photogrammetric method, and the obtained results were verified with flight tests, including certified tests. The application of the photogrammetric method in such analyses with the example of processing of the obtained pictures gives base for the assessment of its usefulness and the directions of development in similar applications.
\end{abstract}

Keywords: flight tests, photogrametry, de-icing system, temperature measurement.

\begin{abstract}
Prowadzenie prób $w$ locie instalacji odlodzeniowych statków powietrznych $w$ warunkach rze-czywistych lub sztucznych, oprócz pomiaru temperatury ogrzewanych powierzchni wymaga weryfikacji pracy instalacji w postaci oceny miejsc osadzania się tworów lodowych i ich roz-miarów. Do ich pomiaru w wymienionych próbach autorzy zastosowali metodę fotograme-tryczna, a uzyskane wyniki zweryfikowali próbami w locie, $w$ tym próbami certyfikacyjnymi. Zastosowanie metody fotogrametrycznej do takich analiz z przykladem przetwarzania uzyski-wanych obrazów daje podstawę do oceny jej przydatności oraz kierunków rozwoju w podobnych zastosowaniach.
\end{abstract}

Stowa kluczowe: próby w locie, fotogrametria, system odladzania, pomiary temperaturowe.

\section{Introduction}

Photogrammetry has a wide application both in documenting geometric figures (the records of construction), making geometric measurements, crash investigation in traffic, etc. The publication refers both to the application of photogrammetry in specific studies of aircraft, such as testing correctness and reliability [1,3] of the work of de-icing system of the airplane ${ }^{1}$, on the level accepted by the requirements of the Aviation Regulations, in this specific case, regulations of $[2]^{2}$. The presented photogrammetric method for such specific applications can be used, provided the time correlation with other parameters of the flight, including the atmosphere is preserved ${ }^{3}$. The presented in this article method is also useful at the temporary verification of the de-icing system of the aircraft, e.g., after the servicing. Its most important advantage is the possibility of conducting research in the area of the carried out aircraft missions, i.e. from the start to landing. The application of other methods of registering the geometry of ice accretions rate and their changes while moving, e.g., by scanning, does not give satisfactory results due to the occurring dynamic changes in shape and situation. The mentioned already other methods are difficult to implement, mainly because the equipment requirement. The photogrammetric method allows making measurements in any moment of the test flight, without using expensive equipment.

The publication presents the analysis and discussion of the obtained results, based on the carried out examinations of the correctness of the work of de-icing systems of M28 aircraft, made in the framework of the co-operation between AGH University of Science and Technology and PZL Mielec Sp. z o.o.[13]. The goal of the article

\footnotetext{
1 Examining the compliance with the regulations can be carried out with other methods e.g., ice tunnels, fights in artificial icy atmosphere, etc. It causes errors of the method and creates specific conditions for the simulation of the phenomenon

2 Requirements of regulations: CS 23. 1419 Ice protection and AMC 23.1419.

3 For these purposes only callibrated sonars are appled for rhe measurement of atmospheric parameters such as: pressure, temperature, humidity, water kontent rate, distribution and size of the water drops, temperature etc.
}

is to prove the usefulness of the mentioned method to detect and geometrize (define the situation and geometric characteristics) of ice accretions arising on the structure of the airplane in artificial or natural atmosphere icing conditions.

The applied in this type of the flight tests and studies other measurement methods, due to the necessity of landing and the related changes in flight parameters and the changes in the height and atmospheric parameters cause changes e.g., ice melting, which significantly disturbs the assessment of the work of systems and the credibility of the data. The presented method additionally gives the possibility of the assessment of the ice acceration rate and ice melting on the surfaces of aircraft not subdued to de-icing procedures.

The presented in the article results refer to the selected tests of operating de-icing systems and the assessment of the geometry of ice accretions applying advanced image analysis methods. The images used in the article are the property of PZL Mielec [7].

\section{Methods of the studies}

The planned and carried out researching experiment and the obtained results made the proof of the correct de-icing system of an airplane. The material to provide the evidence was documenting the occurrence of ice accretions (or their lack) on certain areas of the airplane during the flight in artificial or natural icing ${ }^{4}$.

In the analyzed case, the airplane de-icing system uses the exausts of hot air from turbine engines ${ }^{5}$ which is sent with the ducts alongside the heated - de-iced areas of the aircraft. The proposed and carried out experiment allowed us to show correctness of the work of de-icing system in the aircraft, including thermal changes alongside the heated

\footnotetext{
4 Both the acompanying and tested airplane have the possibility od collecting actual physical parameters of atmosphere during the experiment.

5 The presented method can be applied in other systems de-icing of aircraft, e.g. electric or mechanic.
} 

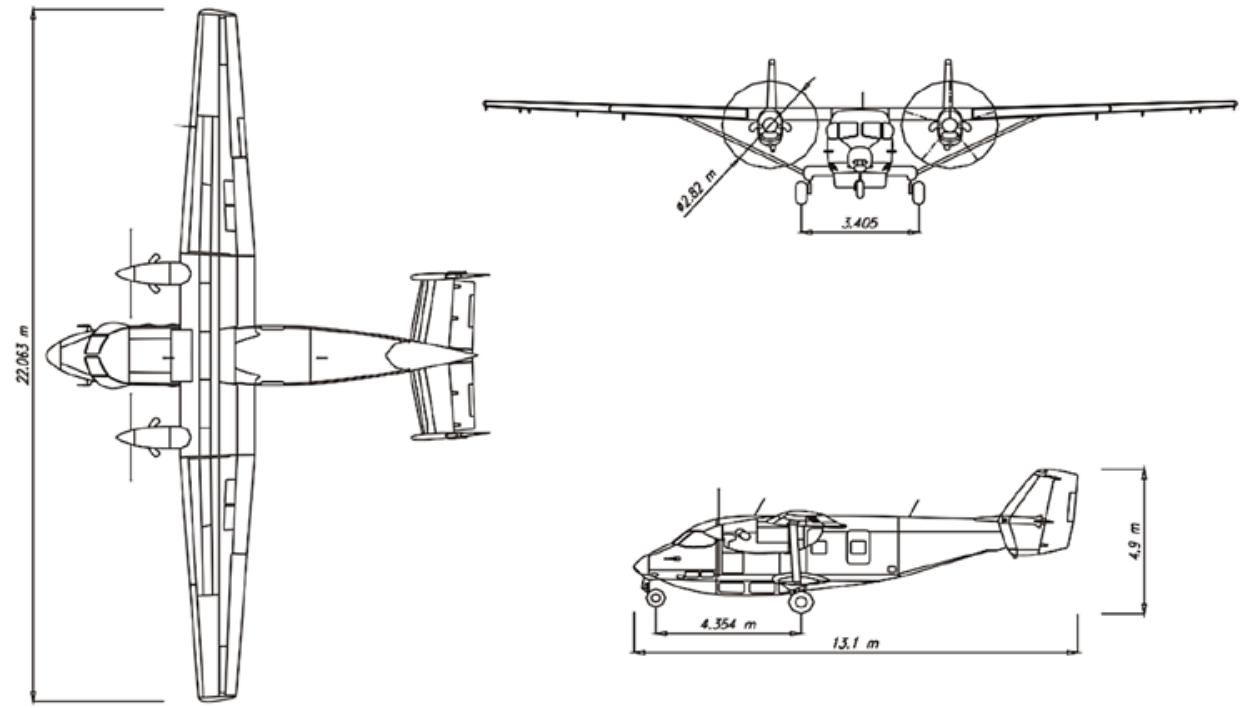

Fig. 1. Based on: http://www.pzlmielec.pl/
In case of other, 3D solids, as aircraft, radial bias can be significant, even making it impossible to make a measurement based on a single photo - so-called oneimage photogrammetry.

Aircraft A (leader) and B (the tested plane) (Fig. 2), taking part in the test were subdued to independent dislocations during the flight, caused by gusts, fluctuations of the stability of their movement and steering - reaching several meters, including the vibration ${ }^{6}$ of their structures caused by the work of the powerplant and air circulation. The application of very short time of the opening of the shutter allowed avoiding the influence of the mentioned factors i.e. dynamic changes of the situation on the quality of photos. The deflection of the structure of fuselage resulting from the load during the flight regarded in numeric analyses.

In the studies we concentrated on doing the analysis in a single image (one-image photogrammetry), while the analyses referred to the tests carried out in different atmospheric conditions i.e. in natural icing areas, determining the characteristic values, and based on them, making the evidence documentation.

The article presents the use images and the analysis of the recorded images of ice accretions and their characteristics. The geometry of the studied airplane was based on the available vector models CAD $[12,13]$.

\subsection{Acquisition of images}

The photogrammetric image is made in a central projection. There can be deformation in the picture resulting from radial dislocations caused by the distortion of the lens, and the inclination of the shape. Thus they cannot be used as a map. Their projection transformations can eliminate the inclination, but they cannot remove deformations resulting from drop or the fact that the photographed object is not flat. These deformations cannot exceed the required accuracy of the measurement of the defined characteristic. Radial deviation can be

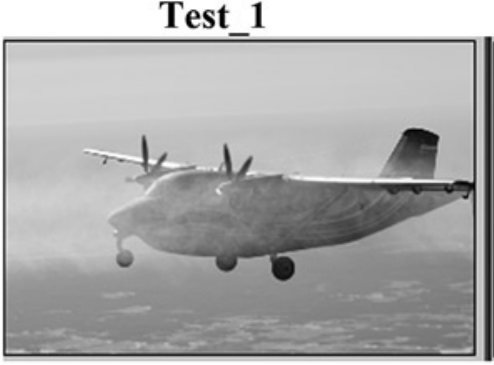

Test_2

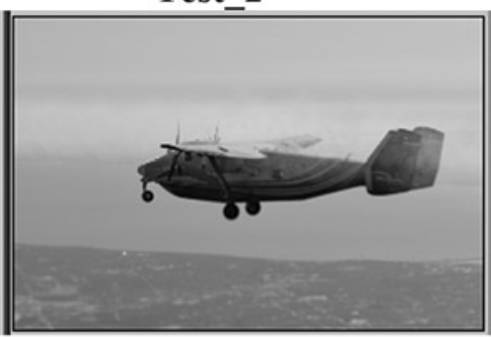

Test 3

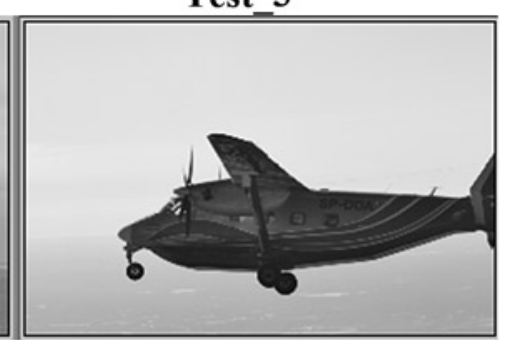

Fig. 3. (Test_1, Test_2, Test_3) the photos defined in the analysis as: Test_1, Test_2, Test_3, (the property of the Polish Aviation Enterprise Ltd. - PZL) (colourless accretions or white (chyba yellow) accretions in artificial icing. In the tests in artificial icing for better identification of the phenomenon, the sprayed water was dyed yellow. The dye was neutral to the result of the tests. Fig. 2 shows a schematic course of the experiment.

\subsection{Data description}

Parameters of icing (atmosphere, flight, powerplants and hot air) were recorded in test flights, according to the flight tests plan. The parameters of real atmosphere and air streams with artificially made conditions of icing the aircraft were verified in the flight calibrated

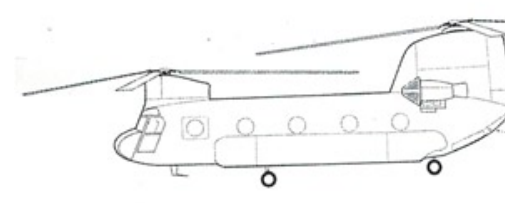

A
B

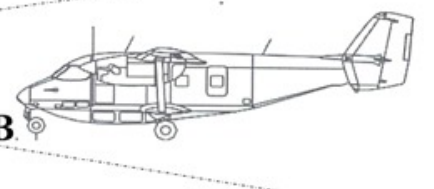

with meteorological sonars. Recording icing parameters of natural and artificial atmosphere was carried out in time correlation with photographic documentation.

The analyses presented in the article were carried out on the photos taken with amateur photo cameras: Nikon D70 and Nikon D3100 with focal lenses of:

Fig. 2. A scheme of the course of experiments and obtaining the data. Aircraft A (photograph and possible artificial icing), $B$ - tested airplane

negligible only for the objects, which bias from 2D (flatness) is small.

6 Usually the ranges of vibration are within the frequency range of $4 \mathrm{~Hz}$ to $60 \mathrm{~Hz}$, depending on the fight speed. 
Test_4

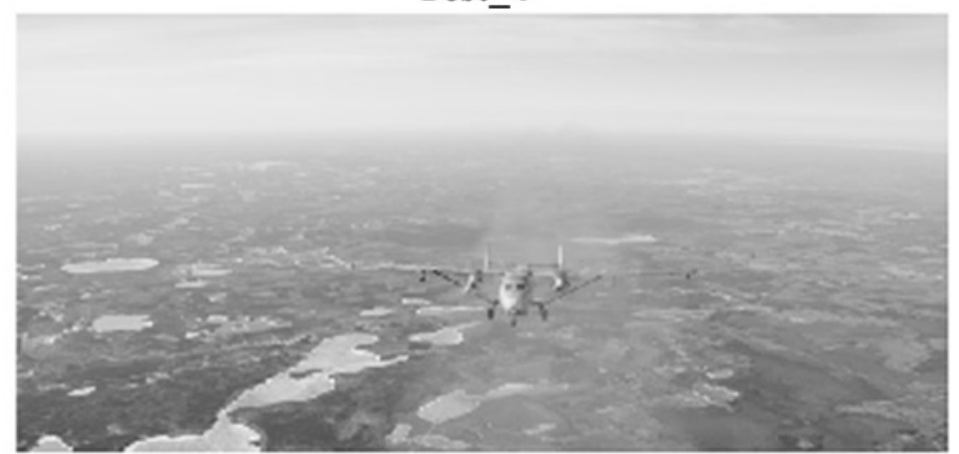

Fig. 3. (Test 4) The photo used in the experiment defined asTest_4 (the property of the Polish Aviation Enterprise Ltd. - PZL

$\mathrm{f}=18.70 \mathrm{~mm}$ and $\mathrm{f}=55.300 \mathrm{~mm}$. The base for the analyses was numerical geometry of the airplane An-28 [5] (Fig. 1, 4.) made in the format*. Igs. For the conducted analyses we applied photos used in the flights in w artificial icing tests, of the following parameters:

- digital image of size 4304 x 2850 pixel i.e. about 13 Mega pixel

- (Test_1, Test_2, Test_3) of resolution 72 dpi (Fig. 3.)

- digital image of size 4677 x 3307 pixel (Test_4) of resolution 400 dpi (Fig. 3).

The photos were taken from the accompanying aircraft A, during tests in the conditions of artificial and natural icing, according to Fig. 2. The photos were written in format*.jpg and subdued to compression to JPEG format of small degree. The details of the analysis presented in this article refer to the photos of artificial icing, because of better possibilities of the analysis, including the presentation of the possibilities of processing with the use of color.

\section{Methods of results processing}

At processing and the verification of the methods of the analysis of data in the form of the digital images and the presentation of the results, the following problems were assumed to be necessary to solve:

a) Identification of ice accretions photographed on the airplane structure (in case of tests with artificial icing in yellow),

b) Identification of the accretions of ice photographed on the wing of the airplane in natural color in case of tests in natural icing conditions, at formerly prepared surface of the wing,

c) Defining of the geometry of ice accretions (area of the accretion).

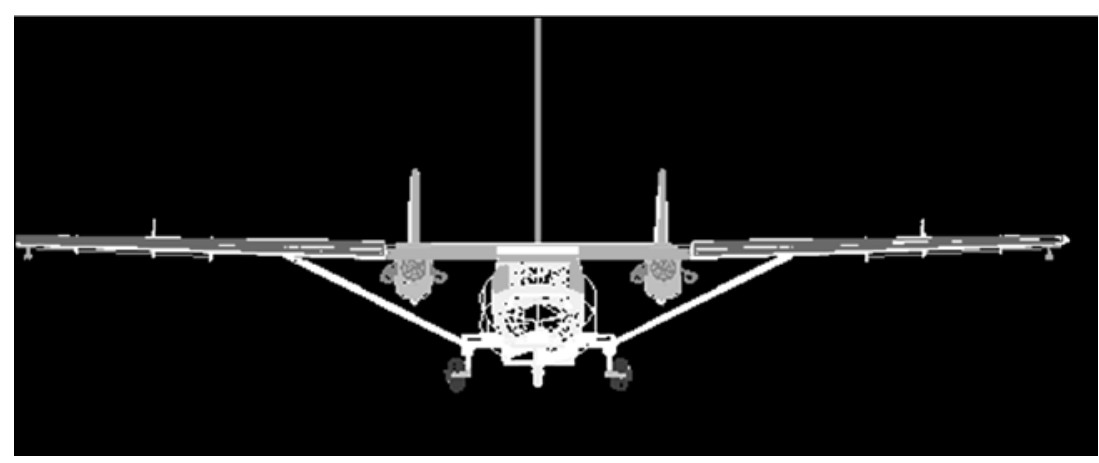

Fig. 4. The applied in the experiment model CAD airplane An-28

The first stage of the carried out analysis and publication was the selection of photos for further processing. Selection referred to the usefulness of the photos in terms of specific fragments of the airplane in the interesting state and during the flight. The article presents the analyses ad and measurements according to the data included in the photo (Fig. 3.) i.e. presenting airplane B seen from the front.

\subsection{Image processing to enhance yellow on the wing of the airplane}

Image processing was carried out in the Matlab environment and then independently in the Adobe Photoshop environment. Experiments for icing in artificial conditions were meant to confirm, among others, the information on the colors occurring on the devices of the airplane. In the presented case, the task was defining the yellow, occurring as the proof of the occurrence or lack of icing, including so-called thermal bridges. Apart from showing that icing occurred, the task was to define the size of its accretions i.e. the area of the ice, and having time difference in the carried out photographs, define the speed of the growth of icing.

To increase the effect of yellow in the photo, in the first step a simple operation of changes in brightness, contrast was carried out as well as the filtration in the mentioned above specialist software.

The application of these operations gave the effects in the form of selected automatically places of the occurrence of icing. At the enlarged image (Fig. 5.3) the left wing can be seen in the original image, as well as the results image processing to enhance yellow.

The improvement of the quality of images by simple operations on the histogram (changes in contrast and the components of the color of the analyzed image) facilitates underlining the places, where yellow coloration occurs and defining the size of the whole area and icing. An independent experiment was to select the areas of the defined brightness component from the whole image, in the Matlab environment. During the carried out experiments, the conversion of the color model $\mathrm{RGB}^{7}$ into CMYK model ${ }^{8}$ was made for better enhancement of yellow. The results of digital processing were shown in Fig. 5. Light areas are represented by the yellow component. Mathematical bases of the transformation of colors and the implementation in the Matlab environment can be found in the literature [4],[5]. The results of the filtration of the original image in program Adobe Photoshop with various filters was presented in Fig. $5(b-d)$. Yellow is the most enhanced with the application of filter Unsharp Mask (Fig. 5d).

In the images transformed in Adobe Photoshop it can be clearly seen that there are also other places of white coloration, which are the effect of the light reflection, and not icing. To eliminate this failure, a subsequent experiment, meaning that the transition from the RGB of the model of colors into CMY model, using Matlab program was carried out. The transformation from RGB environment to CMY (1) and a clear differentiation of yellow channel shows that on the analyzed image light places clearly appeared, thus places of maximal saturation of yellow.

On the other hand, there are no places that were shown earlier in program Abobe Photoshop as the reflection effect.

Transition from RGB color model into CMY was according to:

$$
\begin{aligned}
& R=255-C \\
& G=255-M \\
& B=255-Y
\end{aligned}
$$

where:

\footnotetext{
7 RGB - model of RGB basic colors: Red, Green, Blue.

8 CMYK - model of colors containing complementary components: C-cyan, Y-yellow, M-magenta, K-black.
} 


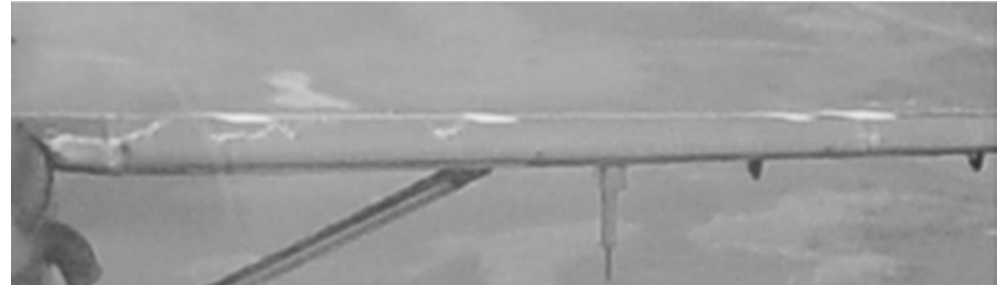

a) Original image

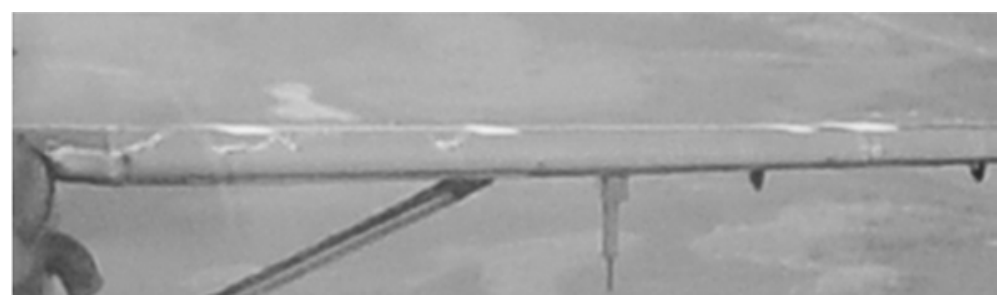

b) Transformation_1

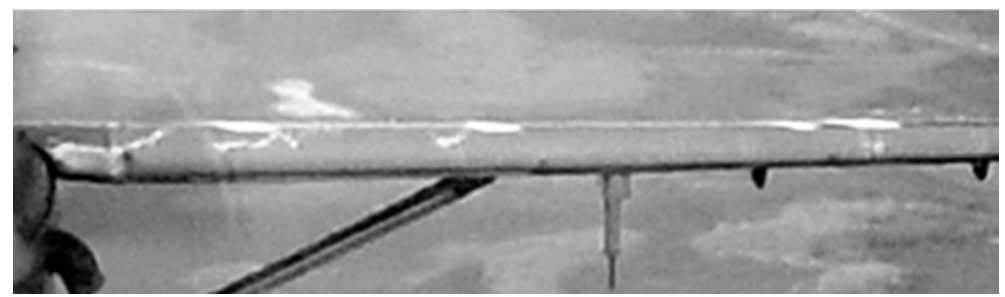

c) Transformation_2

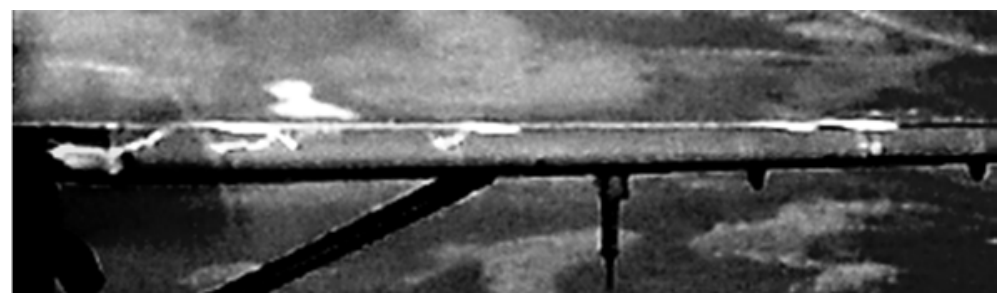

d) Transformation_3

Fig. 5. Results of the original image filtration

RGB - components of the color: R - czerwony, $\mathrm{G}$ - zielony, B - niebieski,

CMY - components of the complementary color (C - niebiesko-zielony, M - fioletowy, Y - yellow)

As a result of the analyses digital images obtained in test referring to the measured atmospheric parameters, the occurrence of places with yellow coloration was shown in the image, which proves the correctness of the work of de-icing system and shows the occurrence of ice accretions in non-heated areas of the airplane.

\subsection{Geometrization of ice accretions.}

To define the situation of ice on the wing and its surface the transformation of the image geometry was made (Fig. 3). The image was recorded from the aircraft flying before the tested airplane. The transformation was made based on the reference model, containing the geometry of airplane written in the vector format. The affine transformation was applied. Its basic parameter of the accuracy assessment is its mean error $\mathrm{m}_{\mathrm{o}}$ determined by the formula (2):

$$
\mathrm{m}_{0}=\sqrt{\frac{\mathrm{V}^{\mathrm{T}} \mathrm{PV}}{\mathrm{r}-\mathrm{u}}}
$$

where:

$$
\begin{aligned}
& \mathrm{v} \text { - matrix of corrections }\left(\mathrm{v}^{\mathrm{T}}-\text { transposed matrix }\right) \\
& \mathrm{P}-\text { weights matrix } \\
& \mathrm{r} \text { - the number of correction equations } \\
& \mathrm{u} \text { - the number of unknowns }
\end{aligned}
$$

After performing the transformation from the system of raster image to the system of airplane (Fig.1., details of defining in $[6,12,13])$, the size of the pixel was calculated and verified by resampling ${ }^{9}$ of the input image. This made basis to calculate the area of ice on not de-iced sections of the airplane. CAD environment (application MicroStation ${ }^{10}$ ) and the overlay to work with rasters - Image Analyst ${ }^{11}$ were applied. To use the CAD model, one had to carry out the transition from 3D model of the airplane (Fig. 1) on the plane parallel to the plane of the taken photo was used. Defined this way 2D system of the model was used as the geometric base for the raster transformation. The view of the image and 2D plane of CAD model, on which the image was transformed, is shown in Fig. 6. By showing the proper characteristic of reference points - on model and digital image the change of geometry of the whole photo. To increase the accuracy of work also other fragments of airplane photo were examined. The applied in the transformation finite elements method ${ }^{12}$ allowed obtaining the accuracy of fitting on the level of $3.6 \mathrm{~mm}$.

Fig. 7. presents the fragment of wing subdued to transformation. Despite very unfavorable geometry of the distribution of photo-points (points selected for transformation were almost in one line), relatively good results were obtained, which is proved by the fact that point no. 4 (Fig. 7a) was automatically ,proposed" by the program in the place, where on the image there is its equivalent (program after calculating the transformation based on 3 points - prompts the situation of subsequent points, which can be accepted or rejected or corrected manually).

Fig. 8. presents CAD model of the wing in the vector format, which was overlapped by digital image as the effect of transformation, confirming the correctness of the accepted methods. The transformation image on points obtained from CAD model allowed the experiments connected with the measurement of the surface elements with a clear yellow component. To carry out the geometrization of ice accretions, the resampling to the ending pixel was carried out.

The calculation of the area is carried out automatically after marking the borders of the area take for the calculation. In Fig. 9. - 1 pixel has the diameter of $10 \mathrm{~mm}$, the area of the region marked white is $4215 \mathrm{~mm}^{2}$. In Fig. 10. - 1 pixel has a diameter of $10 \mathrm{~mm}$, the area of the region marked white is $8387 \mathrm{~mm}^{2}$.

The measurement of the geometry of ice accretions was carried out in the manual way. Using subpixel image analysis and methods of artificial intelligence [7], the accuracy of the processed results can be increased even by one order, i.e. below $1 \mathrm{~mm}$, assuming that the errors of the processing method will not be bigger. The experience of the authors shows that it is reasonable to use subpixel methods, which will mean attributing the image of the gradient value to each pixel. The gradient value is a vector consisting of the amplitude and direction. Then spatial amplitude of the gradient is determined by the equation (3):

$$
g(j, k)=\sqrt{\mathrm{g}_{\mathrm{r}}(\mathrm{j}, \mathrm{k})^{2}+\mathrm{g}_{\mathrm{c}}(\mathrm{j}, \mathrm{k})^{2}}
$$

\footnotetext{
9 resampling - calculating pixels and giving them another size of the pixel 10 Aplication MicroStation by Bentley

11 Image Analyst - overlay by Intergraph on MicroStaion environment

12 Transformation by finite elements method (FEM) polega means the transformation of the image, after earlier division into the grid.
} 


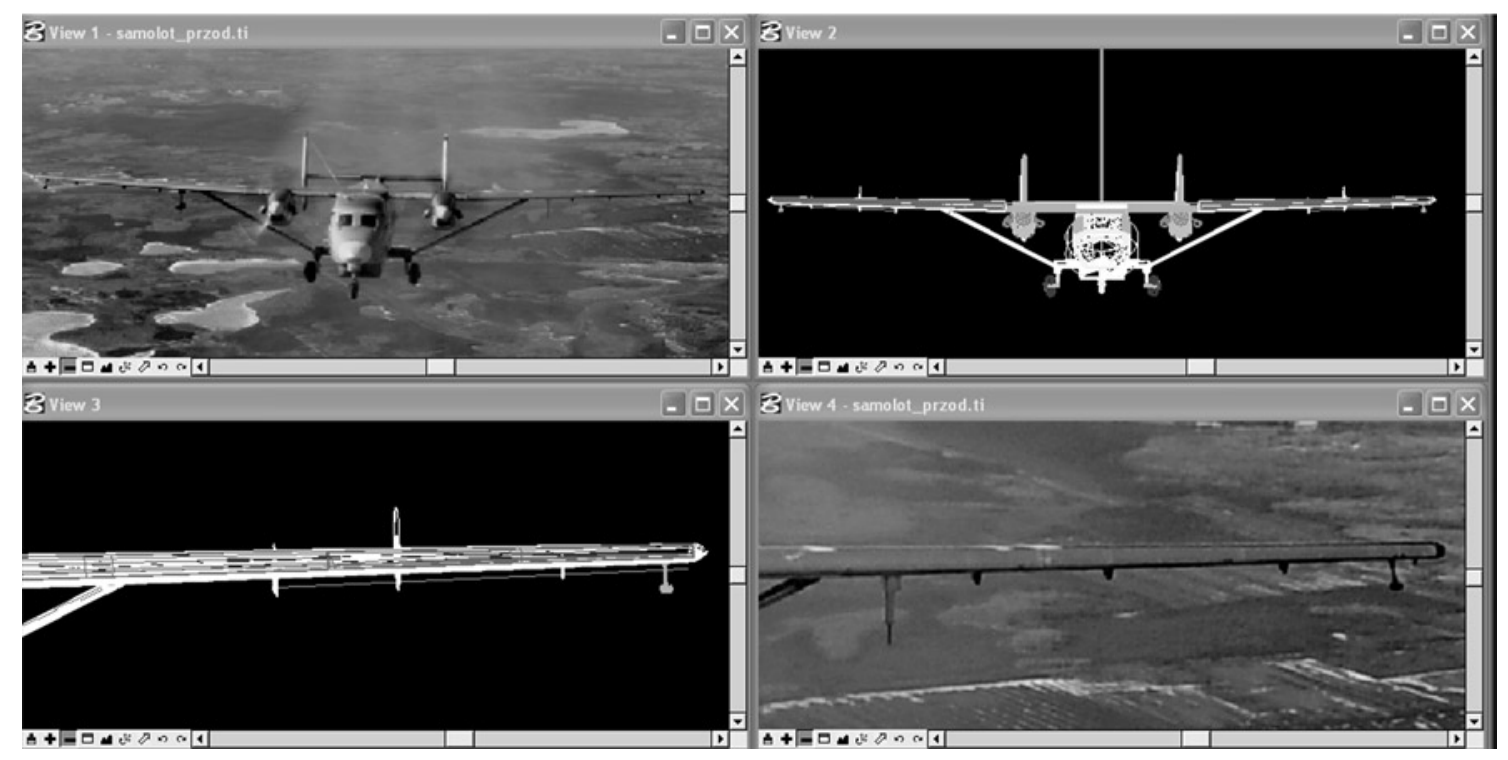

Fig. 6. The view of the program Image Analyst and MicroStation with CAD model and the image recorded during the flight

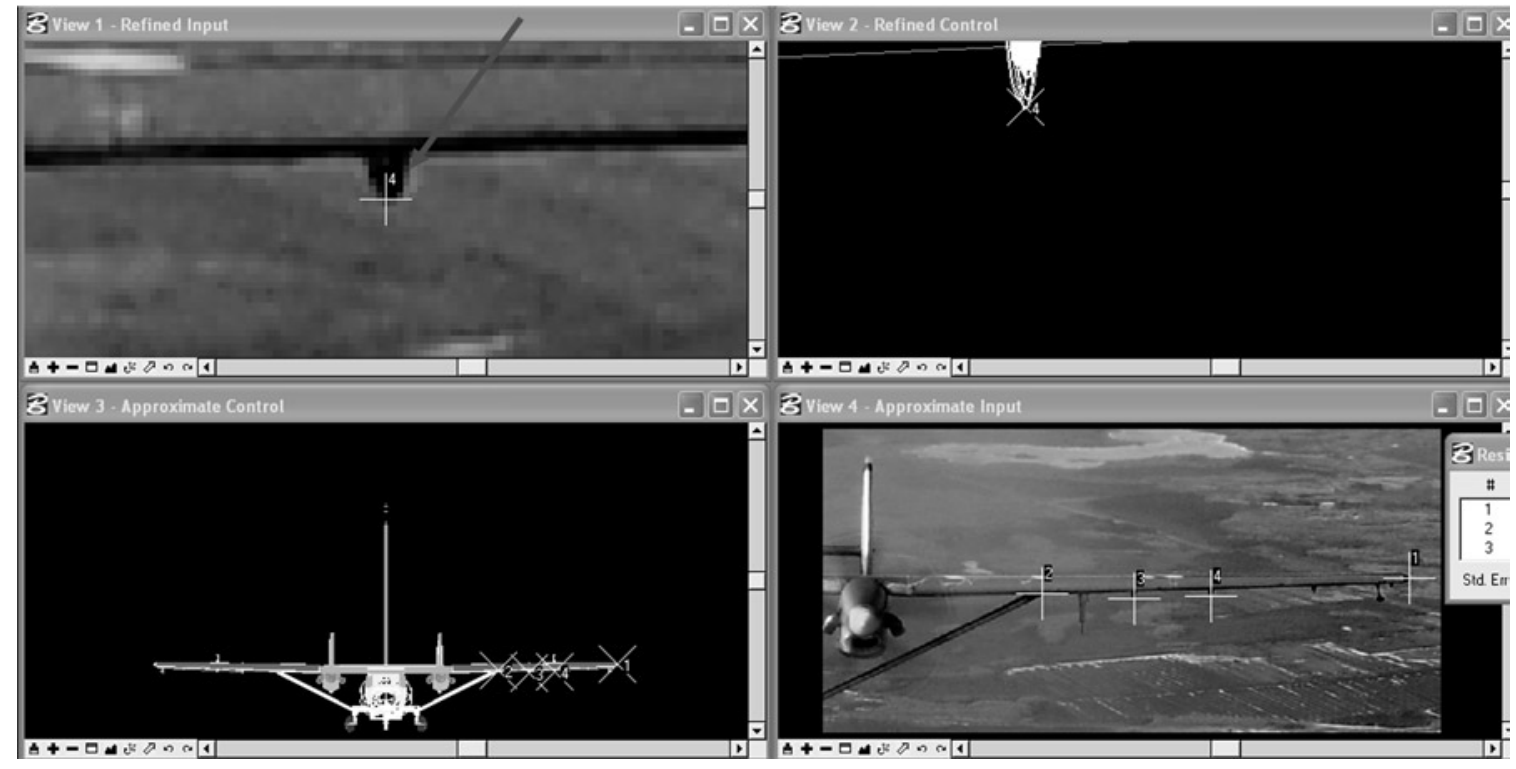

Fig. 7a. Distribution of points for the transformation. Red arrow marks the mentioned in the text point no. 4

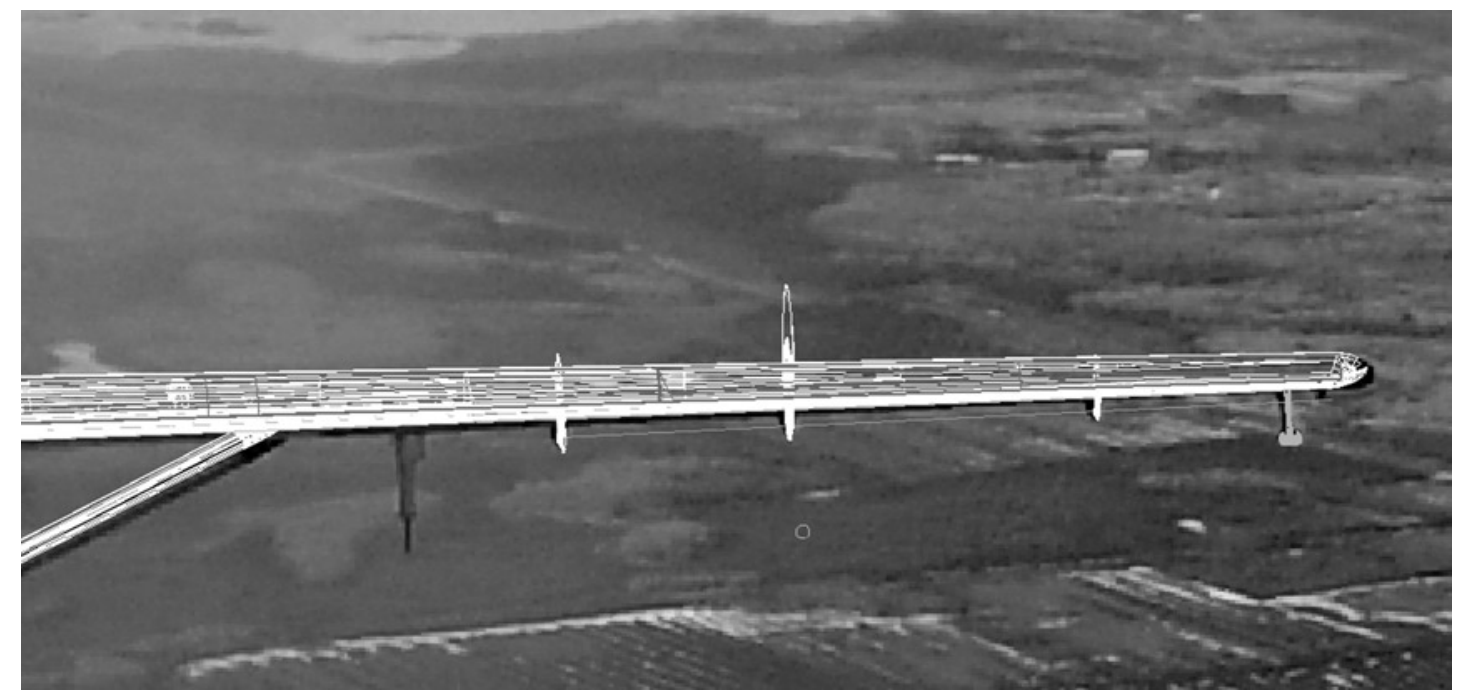

Fig. 8. Overlapping the digital image on CAD model 


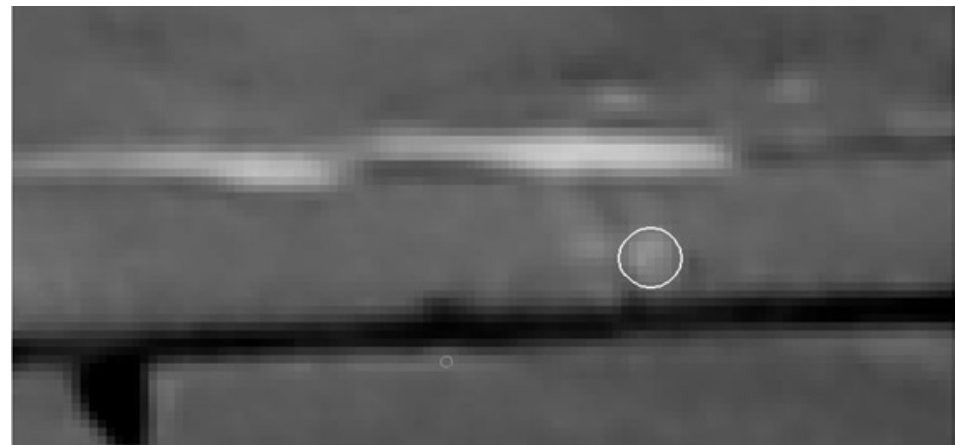

Fig. 9. Augmented fragment of the image

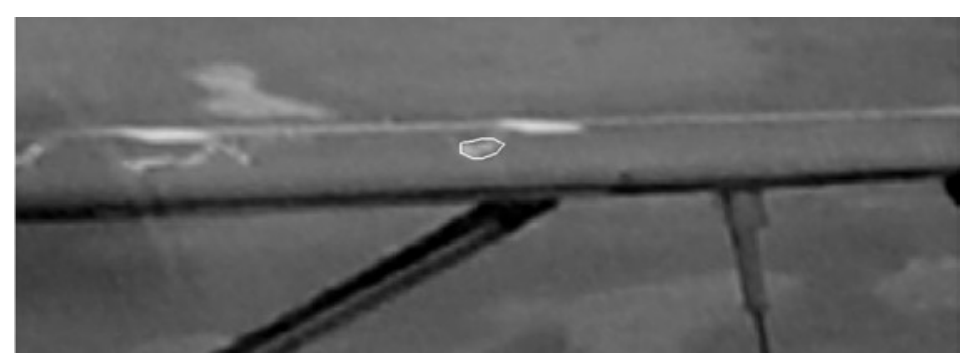

Fig. 10. Augmented fragment of the image

where $\mathrm{g}_{\mathrm{r}}(j, k)$ and $\mathrm{g}_{\mathrm{c}}(j, k)$ are gradient calculated towards the rows (r) and columns (c). The direction of the spatial gradient referring to the axis of rows is counted in the following way (4):

$$
(j, k)=\arctan \frac{g_{c}(j, k)}{g r(j, k)}
$$

Subpixel edge accuracy is achieved by adjusting the polynomial of the second degree towards the gradient. There, where the function achieves maximum subpixel localization will occur. The essence of subpixel image analysis [8],[9] (application of the second derivative as a method of marking the position of the points on the edge) was

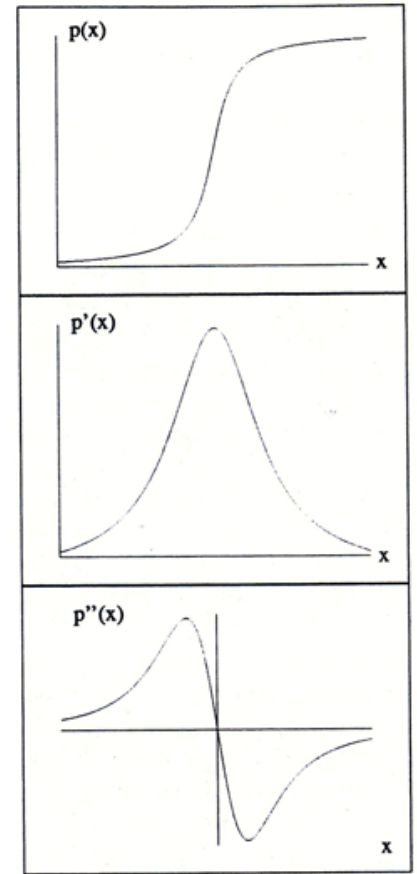

Fig. 11. The essence of subpixel analysis presented in Fig. 11. where: the inflection point on an exemplified edge as function $\mathrm{p}(\mathrm{x})$, its equivalent in the first derivative (maximum function $\mathrm{p}^{\prime}(\mathrm{x})$ ) and second derivative (place of zero, function $\mathrm{p} "(\mathrm{x}))$.

Formulae (5) and (6) define first and second derivative counted on the digital image.

$$
\nabla f=\left[\begin{array}{l}
\frac{\partial f}{\partial x} \\
\frac{\partial f}{\partial y}
\end{array}\right]
$$

where:

$\nabla f-$ is the first derivative of the components in direction $\mathrm{x}$ and $\mathrm{y}$ $\left(\frac{\partial f}{\partial x}, \frac{\partial f}{\partial y}\right)$.

The calculation of the second derivative runs according to the formula:

$$
\nabla^{2} f(x, y)=\frac{\partial^{2} f(x, y)}{\partial x^{2}}+\frac{\partial^{2} f(x, y)}{\partial y^{2}}
$$

where:

$\nabla^{2} f(x, y)$ - calculation of second derivative towards $\mathrm{x}$ and $\mathrm{y}$ based on the components :

$$
\left(\frac{\partial^{2} f(x, y)}{\partial x^{2}}, \frac{\partial^{2} f(x, y)}{\partial y^{2}}\right) .
$$

In further experiments the authors intend to increase the accuracy of work by the application of the concept of the use of the first and second derivative, which will allow the increase of the quality of the papers of this type.

\section{Conclusions}

In the carried out experiments the visual assessment and manual measurements of ice accretions due to the improvement of the quality of input images (Fig. 2, 3). The authors of the article can see the possibility of the automation of measurements and the increase of accuracy. The application of results of the analysis, of the character of evidence is in a non-published document, the owner of which is PZL Mielec Sp. z o.o. Sikorsky Company $[12,13]$.

As a result of the flight tests processing of digital images, it was stated that the application of photogrammetric methods to testing the de-icing systems of airplanes, it is jest reliable and acceptable from the point of view of the information accuracy. The use of neutral substances coloring the water suspension used to sprinkle the airplane during the tests in artificial icing conditions is acceptable and comfortable solution in the understanding of the accuracy of the obtained results, on the level of single millimeters (the accuracy of transformation was calculated on the level $\approx 0,5$ pixel and such accuracy was accepted as the accuracy of manual vectorization of theplaces of icing).

Comparison to the geometry of the airplane (pt. 3.2) confirmed the correctness of the approach connected with the processing of the image and geometrization of its details.

It was found sensible to apply subpixel image analysis in the future, which will improve the accuracy of the results. For the discussed case it was the accuracy below $1 \mathrm{~mm}(0.1$ pixel). This refer to all the elements of the geometry of the solid and their situation in the struc- 
ture of the airplane. An important element of preparing the airplane for tests in natural conditions is painting the surfaces interesting for us with dark and mat paint, which will decisively increase the accuracy of the analysis. A subsequent element decisively improving the quality of the obtained results is higher number of photos, including the ones taken by the conjugated cameras.

In the indicated improvements the authors of the article can see the possibility of further increase of the accuracy of the carried out analyses by the development and implementation of the methods of artificial intelligence [7] and subpixel image analysis [8].

In subsequent experiments one can apply photo cameras with the image sensor of higher resolution, which should additionally increase the accuracy of the work. Independent research can be carried out on the optimization of the distance of photographing to the studied air- plane or the application of experiments with UAV technology, which becomes more and more popular [10, 11].

Icing on the surfaces of the airplane can occur in several forms: white porous ice, transparent ice, cracked ice, etc. Some forms of icing will allow seeing the painting of airplane, and other will reflect the light. In case of testing de-icing systems of the airplane in natural conditions, painting the de-iced surfaces in dark mat paints is suggested.

The authors also believe in the meaning of studies extending the scope of the application of sensors with modern techniques of laser scanning, which in recent years has been gaining more and more popularity and scope [11]. The authors wish to thank the Board of the Polskie Zakłady Lotnicze Sp. z o.o. in Mielec for making available the results of tests and photos to write this article.

\section{References}

1. Brzeczek J., Pietruszka J., Polskie Zakłady Lotnicze Sp. z o.o.; Flemming R.J., Bernstein B.,C., Leading Edge Atmospherics. "Certification Flight Tests in Natural Icing of the PZL Mielec M28 Commuter Turboprop Airplane" Praha SAE 2015 International Conference on Icing of Aircraft, Engines, and Structures 22-25 June 2015 Prague, Czech Republic.

2. Certification Specifications CS-23 (Normal, Utility, Aerobatic, and Commuter Category Aeroplanes) with AMC, GM, Amendment 4, 15 July 2015 ,

3. Golec P., Brzęczek J., Meeting Reliability Requirements for Rotor Ice Protection Systems Design, Diagnostyka $2014 ; 15$ (1): $22-31$.

4. Gonzalez R. C., Woods R. E., Eddins S.L., Digital Image Processing Using MATLAB, 2nd edition, Gatesmark Publishing 2009.

5. Gonzalez R. C., Woods R. E., Digital Image Processing (3rd Edition). Prentice Hall Upper Saddle River, New Jersey 2007.

6. Instrukcja Użytkowania w Locie Samolotu M 28.

7. Mikrut S. (praca zbiorowa - Czechowicz A., , Gryboś P., Jachimski J., Mikrut S., Mikrut Z. , Pawlik P., Tadeusiewicz R. pod redakcją naukową dr inż. Sławomir Mikrut) Sieci neuronowe w procesach dopasowania zdjęć lotniczych. Wydawnictwa AGH - AGH University of Science and Technology Press, Kraków 2010.

8. Mikrut S. Przydatność algorytmów podpikselowej detekcji cech w wybranych zagadnieniach fotogrametrycznych. Archiwum Fotogrametrii, Kartografii i Teledetekcji - Archives of Photogrammetry, Cartography and Remote Sensing 2009; 19: 299-308.

9. Mikrut S., Wpływ skanowania i kompresji według standardu JPEG na wykrywanie obiektów liniowych i punktowych na obrazach cyfrowych. Rozprawa doktorska AGH, Kraków 2003. Unpublished.

10. Mikrut S., 2016, : Classical Photogrammetry and UAV - Selected Ascpects. Int. Arch. Photogramm. Remote Sens. Spatial Inf. Sci., XLI-B1, 947-952.

11. Mikrut S., Kohut P., Pyka K., Tokarczyk R., Barszcz T., Uhl T. : Mobile Laser Scanning Systems for Measuring the Clearance Gauge of Railways: State of Play, Testing and Outlook. Sensors 2016; 16(5): 683, https://doi.org/10.3390/s16050683.

12. Opracowanie zbiorowe, Raport AGH, pt. "Analysis of Digital Images Concerning PZL-M28 SP-DAA Airplane" wykonany przez AGH dla PZL Mielec 2014. Unpublished.

13. Opracowanie zbiorowe, Raport AGH, pt. "Wykonanie testów i analiz w zakresie określania geometrii zewnętrznej płatowca metodami fotogrametrii i skaningu" wykonany przez AGH dla PZL Mielec 2015. Unpublished.

Józef BRZĘCZEK

State Higher Vocational School them. Stanislaw Pigon in Krosno

Polytechnic Institute

Department of Mechanics and Mechanical Engineering

ul. Wyspiańskiego 20, 38-400 Krosno, Poland

\section{Sławomir MIKRUT}

Faculty of Mining Surveying and Environmental Engineering

AGH University of Science and Technology

Department of Geoinformation, Photogrammetry

and Environmental Remote Sensing

al. Mickiewicza 30, 30-059 Cracow, Poland

E-mails: jbrzeczek@gmail.com, smikrut@agh.edu.pl 